\title{
THE HISTORY OF THE GARDEN HYACINTHS
}

\author{
C. D. DARLINGTON, J. B. HAIR and R. HURCOMBE
}

John Innes Horticultural Institution, Bayfordbury, Hertford, Herts

\section{CONTENTS}

Received 14.iv.49

I. Origins . . . . . . . . . . . . 233

2. Varieties, Sports and Names . . . . . . . 234

3. Chromosomes of the Varieties . . . . . . 235

(i) The Complement . $\quad . \quad$. $\quad . \quad$. $\quad . \quad$. 235

(ii) Sports, New Chromosomes and Corrections . . 236

4. Balance in the Unbalanced Varieties . . . . . . 240

5. The Effects of Selection . . . . . . . . 243

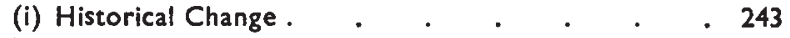

(ii) Present-Day Varieties . . . . . . . . . . 243

(iii) Colour and Chromosome Number . . . . . 244

(iv) Leaf Number . . . . . . . . . . 246

6. Pollen Grains of the Near Tetraploids . . . . . 247

7. Summary . . . . . . . . . . 250

References . . . . . . . . . 251

\section{ORIGINS}

THE origin of the garden hyacinth is simple enough, and its improvement recent enough, for us to describe its history more accurately than that of most garden plants. Krelage in his recent account is able to refer not only to the illustrations but to the actual varieties raised during the last three hundred years as a record of the achievements of successive generations of hyacinth breeders.

Hyacinthus orientalis has been collected during the last thirty years. We have seen specimens flowering in the gardens of $\mathrm{Mr} \mathrm{E}$. A. Bowles (from Palestine), Major A. Pam (from Syria) and Colonel F. C. Stern (from the Taurus Mountains). With their spikes of half a dozen pale blue flowers they agree with the figures and descriptions of Dodoens, Clusius, Besler, L'Obel, Sweerts and Parkinson between ${ }_{1562}$ and 1640 . In this period, just after its introduction from Turkey, there was little change beyond the appearance of white and pink and double mutants or segregates, and of larger spikes. Then came a great advance. Van Kampin's catalogue of 1739 lists nearly 400 varieties of hyacinths-300 double. In $175^{2}$ Guyot writes (according to Zirkle) : "Hyacinths are all either blue or white; some have a little rose colour. . . . Yellow hyacinths will never be produced."

Before 1768 lilac and yellow colours had appeared. Dutch breeders had raised the 1670 varieties numbered and named at that time in the great treatise of the Marquis de Saint Simon. And they had raised many more which had failed to survive. Since that time another three thousand or more have been raised and named, 
recombining the pigment mutations. Of all these only a hundred or so survive. The need for denser and denser spikes for show led first to the selection of double flowers. This was succeeded by a selection of fasciated spikes which give the same dense effect with earlier flowering and a more rapidly propagating bulb. These tendencies were noted in the Gardeners' Chronicle of 22nd March 1862 and 3rd April 1886. Now, few double varieties are found in commerce and none of them of the flamboyant monstrosity of former times.

The direction of yet a third change is indicated by Shirley Hibberd (1880) who says, that in 1873 he had flowered some 500 of the surviving varieties. "Blue and white varieties were in most cases superior in quality to the red. Thus it appears that in raising flowers by cross breeding we must expect to lose quality with every gain in departure from the normal type." We have fancy colours, he considers, at the price of a loss of vigour.

In all this history there is no evidence of hybridisation. The garden hyacinth is derived like the sweet pea from a single, not very variable, wild ancestor. The chromosome complement bears out this conclusion : for the whole range of varieties the forms of the chromosomes are, as we shall see, almost invariable and they do not occur in the only other species of the genus, Hyacinthus amethystinus $(2 n=28$ : Darlington, 1933).

\section{VARIETIES, SPORTS AND NAMES}

New hyacinth varieties have been chiefly raised from seed and named by the breeder when introduced. These varieties produce bud sports, i.e. somatic mutations, especially for colour and doubleness, but perhaps also for quantitative characters such as vigour. Most supposed mutations are lighter in colour than the parent and dark blue varieties seem to give most mutants. They are of the kind expected of genuine somatic mutations, recessives being commoner from dominants than the reverse. To these mutants, entirely new names may be given and the result is then straightforward, as we shall show

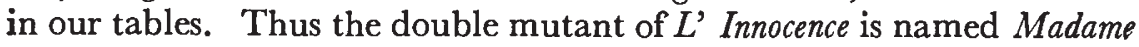
Sophie. But the result is not straightforward in two other situations.

In the first place, new names have often not been given. Thus Kersten (1889) says that there are three Queen of the Blues-from Haarlem, Overveen, and Hillegom. Also Grand Vainqueur was known in 1874 in white, yellow, and pink forms, both single and double. Again there are single and double forms of La Grandesse, the single being the one we have studied.

In the second place, new names are sometimes given when no obvious mutation has occurred. The same variety is then known under synonyms, e.g. :-

$\left\{\begin{array}{l}\text { Maria Catherina } \\ \text { Robert Steiger }\end{array}\left\{\begin{array}{l}\text { Salmonetta } \\ \text { Orange Boven }\end{array}\left\{\begin{array}{l}\text { Mme. du Barry } \\ \text { Scarlet O'Hara of Blom } \\ \text { Tubergen's Scarlet }\end{array}\left\{\begin{array}{l}\text { Bismarck } \\ \text { Blue Queen }\end{array}\left\{\begin{array}{l}\text { Queen o' Whites } \\ \text { Blom's Gem }\end{array}\right.\right.\right.\right.\right.$


Our chromosome studies suggest other pairs as candidates for synonymy, such as :-

\section{$\left\{\begin{array}{l}\text { Pink Perfection } \\ \text { Princess Margaret }\end{array}\left\{\begin{array}{l}\text { Dr Stresemann } \\ \text { Winston Churchill }\end{array}\right.\right.$}

A third special difficulty has arisen through the sale of immature bulbs as "miniature" hyacinths for bedding and forcing. For these Messrs Sutton's, in 1920, adopted the name of Cynthella hyacinths. The flowers being smaller and the spikes looser than those of the mature variety, the trade did not like to give them the same varietal names as the mature forms and a whole series of sprightly new names were invented for them such as Minnie and Maggie and Fair Annie. Owing to the disappearance from cultivation of many varieties in their mature form, we have had to resort to these Cynthellas and we have marked them (C). We have tried to make out their synonymy with the help of the chromosome identity so far as we could, e.g. :-

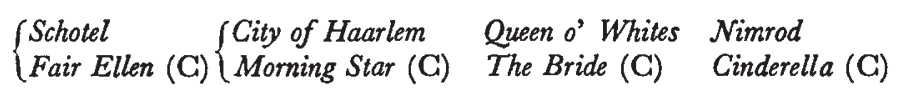

\section{CHROMOSOMES OF THE VARIETIES}

\section{(i) The complement}

The importance of the hyacinth for us depends on the variations in its chromosome complement which the living records of its evolution are still capable of displaying. We can record the achievements of the plant breeder in each period, not only by the forms produced but by the chromosomes determining these forms. Moreover, in its chromosome structure this plant is uniquely favourable for such an inquiry.

The hyacinth has five distinct chromosome types which vary in number independently (within limits which we shall examine) in the improved varieties so that scores-or perhaps hundreds - of different chromosome combinations can be recognised under the microscope. The haploid chromosome set of eight may be represented, after slight shortening with pre-treatment and Feulgen staining, as follows :-

\begin{tabular}{|c|c|c|c|}
\hline $\mathrm{L}-17 \mu$ & $\mathrm{L}-20 \mu$ & $\mathrm{M}-9 \mu$ & $\mathrm{S}_{1}-5 \mu$ \\
\cline { 2 - 3 } & $\begin{array}{c}\mathrm{L}-19 \mu \\
\text { nucleolar }\end{array}$ & $\mathrm{M}-9 \mu$ & $\mathrm{S}_{2}-5 \mu$ \\
\hline
\end{tabular}

The sub-types of L's and S's cannot be told apart in every cell. They have not, therefore, been recorded for individual pollen grains and, only in our later work, for individual varieties.

Yet another, but less certain, distinction concerns the width of the nucleolar constriction. In one of the four $\mathrm{L}^{n}$ chromosomes in 
Myosotis, L' Innocence and its mutant Mme. Sophie it seems to be weaker than in the other three which are normal.

Previous workers had counted and classified the complements of 46 varieties (seedlings and somatic mutants). We have dealt with another 6I. The total of 107 are recorded for the chromosomes in relation to their dates and modes of origin, and colours, in table $\mathrm{I}$.

\section{(ii) Sports, new chromosomes and corrections}

All undoubted bud sports proved to have the same chromosome numbers as their parent varieties, with one exception, Queen of the Whites has an $\mathrm{S}_{2}$ chromosome in place of an $\mathrm{S}_{1}$ found in Queen of the Blues : $4 \mathrm{~S}_{1}+2 \mathrm{~S}_{2}$ has become $3 \mathrm{~S}_{1}+3 \mathrm{~S}_{2}$, this implies two changes but it is not so improbable as it seems since both changes involve a movement towards normal balance.

Three varieties, one a bud sport, have new chromosome types, as follows :-

(i) Madame du Barry, introduced in 1920 , arose as a sport from the normal diploid variety Distinction. It has a deficiency amounting to two-thirds of one arm of an $\mathrm{L}$ chromosome and has lighter red flowers than its bud-parent. The loss of the segment has apparently revealed a recessive colour character. Such a deficiency-heterozygote arising somatically is unique among diploid organisms (fig. I A). A reciprocal change was found in the parent variety (plate I, fig. I).

(ii) Fireball, another red variety, arose in 1867 as a seedling. It is a triploid but has a translocation from $\mathrm{L}$ to $\mathrm{S}_{2}$ (or an interchange between them) giving two new types of chromosomes (fig. IB).

(iii) Grace Darling is a bogus Cynthella name and not a period name. We do not know its genuine synonym among the old varieties. It has one $\mathrm{M}$ chromosome with a subterminal centromere, i.e. deficient in the short arm.

Two losses and one interchange thus represent the sum of observable structural changes that have arisen in the hyacinths in nearly 400 years' cultivation. In the beginning, before the differentiation of the varieties, the chromosome uniformity must have been even greater.

The chromosome studies enable us, while confirming the documentary evidence of origin for some varieties, to contradict it for others. The evidence must be weighed in each case, as follows :-

(i) $\mathrm{Mr}$ Dames, the only pink variety with a high chromosome number, is said by some connoisseurs to be a cross between a pink mutant (Etta) of Lord Balfour and La Victoire both normal diploids. The origin of a near tetraploid at one step from two diploids is unlikely and is doubtless the usual breeders' guess. An alternative guess is Jacquis $\times$ Amiral Courbet: this we cannot test since the two parents are of unknown number.

(ii) Cardinal Wiseman is said to have given rise to Marconi as a bud sport. If the counts and names are right it has, therefore, lost three 

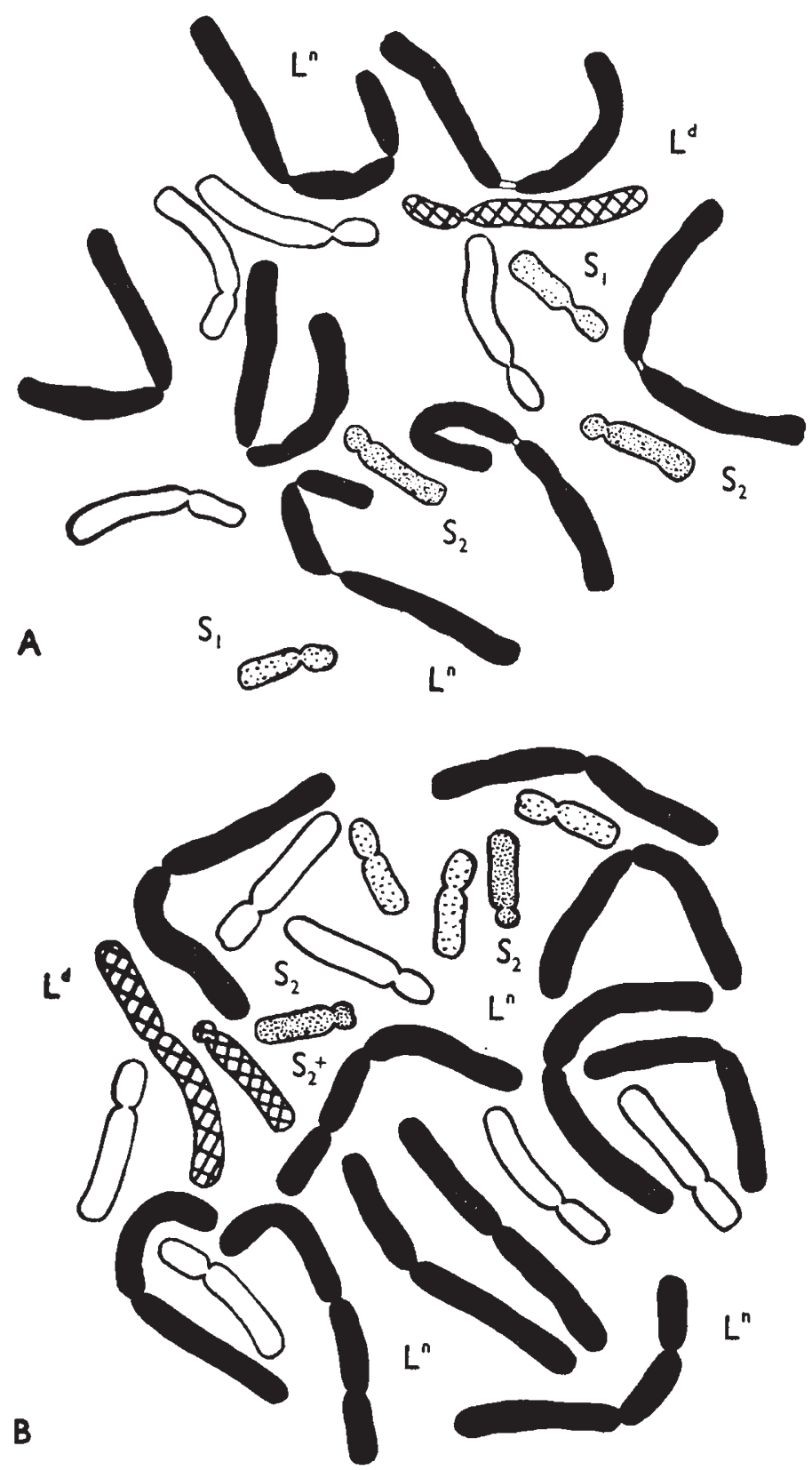

Fig. 1.-Complements of varieties with aberrant chromosomes.

A. Madame du Barry with a deficient $\mathrm{L}^{d}$ arose as a bud sport from the normal diploid Distinction.

B. Fireball, a triploid variety with an interchange, giving a short $L^{d}$ and a long $S_{2}+$. $\times 2000$. 
chromosomes and become balanced. The count, however, was an early one by De Mol from sections, and the complement very unusual

TABLE I

\section{Hyacinth varieties classifed ( 107 forms)}

$\mathrm{L}, \mathrm{M}$ and $\mathrm{S}$ chromosome numbers are given according to the author named, and $\mathrm{L}^{n}$ and $\mathrm{S}_{\mathbf{2}}$ sub-classes where recorded.

$\mathrm{D}=$ Darlington, 1926, 1929. $\mathrm{D}$ and $\mathrm{M}=$ Darlington and Mather, 1944. $\mathrm{S}=$ Stow $193^{\circ}$. Hair $=$ Hair unpub. $M=$ de Mol, I92 I. $R H=R$. Hurcombe unpub. $U=U p c o t t, ~ I 937$.

All varieties are seedlings except those labelled mut., somatic mutant.

Dates of introduction chiefly from Krelage, 1947 : usually 25 years after sowing seed.

B, blue flower ; BB, dark blue. (C) Cynthella name. (d) double flowers.

\begin{tabular}{|c|c|c|c|c|c|c|c|}
\hline \multicolumn{8}{|c|}{ A. Diploids : $8 \mathrm{~L}+4 \mathrm{M}+4 \mathrm{~S}=16$ (35 varieties, I mutant) } \\
\hline Name & Author & Date & Colour & Name & Author & Date & Colour \\
\hline 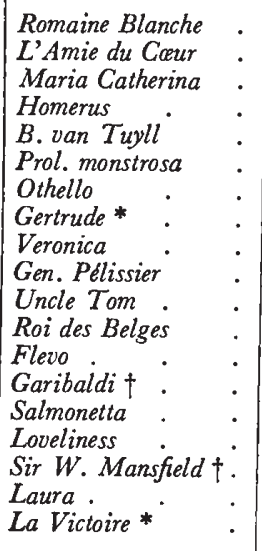 & $\begin{array}{l}\text { M } \\
, " \\
, " \\
, \\
, \\
, \\
, \\
, \\
, \\
\text {," } \\
\text { Hair } \\
\text {," } \\
\text { Ü } \\
\text { Hair } \\
\text { S }\end{array}$ & $\begin{array}{l}1580 \\
1820 \\
1830 \\
1840 \\
1841 \\
1844 \\
1848 \\
1850 \\
1854 \\
1855 \\
1856 \\
1860 \\
1862 \\
1869 \\
1870 \\
1870 \\
1873 \\
1875 \\
1875\end{array}$ & \begin{tabular}{|c} 
white \\
pink \\
red \\
pink \\
$\ldots ̈$ \\
BB \\
red \\
,$’$ \\
BB \\
red \\
white \\
red \\
salmon \\
B \\
purple \\
lilac \\
red
\end{tabular} & 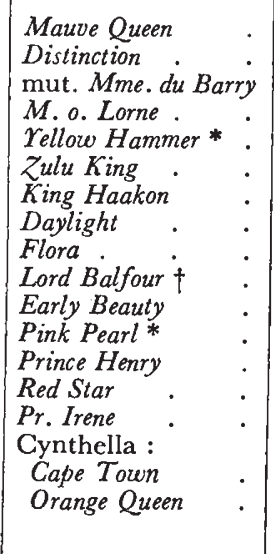 & \begin{tabular}{|} 
Hair \\
", \\
M̈ \\
Hair \\
M \\
,$"$ \\
Hair \\
,$"$ \\
", \\
Hair \\
Hair \\
"
\end{tabular} & $\begin{array}{c}1875 \\
1880 \\
(1920) \\
1881 \\
1883 \\
1890 ? \\
1900 \\
1893 \\
1900 \\
1900 \\
1903 \\
1905 \\
1910 \\
? \\
1945 ? \\
\ldots \\
\ldots\end{array}$ & $\begin{array}{c}\text { mauve } \\
\text { red } \\
\text { pink } \\
\text { yellow } \\
\text { yellow } \\
\text { BB } \\
? \\
\text { salmon } \\
? \\
\text { BB } \\
\text { pink } \\
\text { yellow } \\
\text { red } \\
\text { ", } \\
\text { red } \\
\text { salmon }\end{array}$ \\
\hline \multicolumn{8}{|c|}{ B. TRIPLOIDS: $12 \mathrm{~L}+6 \mathrm{M}+6 \mathrm{~S}=24$ (22 varieties, 6 mutants) } \\
\hline 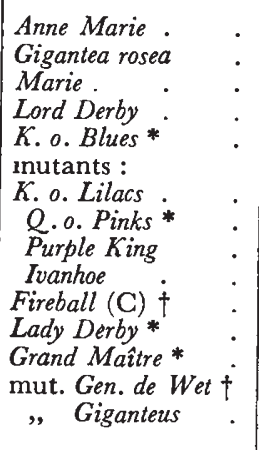 & $\begin{array}{l}\text { RH } \\
\text { M } \\
\text { D } \\
\mathrm{D} \\
\mathrm{M} \\
\text { Hair } \\
\text { M } \\
\text { Hair } \\
\text { Hair } \\
\text { M̈ } \\
\text {, } \\
\text { ", }\end{array}$ & $\begin{array}{l}1765 ? \\
185 \% \\
1860 \\
1860 \\
1865 \\
1883 \\
180 \\
(1903) \\
(1909) \\
(1920) \\
1867 \\
1869 \\
1870 \\
(1901) \\
(1874)\end{array}$ & $\begin{array}{c}\text { pink } \\
\text { ’’ } \\
\text { BB } \\
\text { B } \\
\text { BB } \\
\text { lilac } \\
\text { pink } \\
\text { purple } \\
\text { BB } \\
\text { red } \\
\text { pink } \\
\text { BB } \\
\text { pink } \\
\text { " }\end{array}$ & $\begin{array}{lr}\text { Bismarck* } & \cdot \\
\text { Moreno* } & : \\
\text { Pr. Victoria }(\mathrm{C}) & : \\
\text { Electra } \dagger & : \\
\text { Pink Perfection } & : \\
\text { mut. Marconi } * & : \\
\text { Dreadnought } & : \\
\text { Fan Bos } \dagger & : \\
\text { Pr. Margaret } & : \\
\text { Wedgwood } & : \\
\text { Gerrit van der Mey } & : \\
\text { Perfection (C) } & : \\
\text { Rosabella (C) } & : \\
\text { Cyclop (C) } & :\end{array}$ & $\begin{array}{c}\text { Hair } \\
\text { D } \\
\text { Hair } \\
\text { D and M } \\
\text { Hair } \\
\text { D } \\
\text { Hair } \\
\text { ", } \\
\text { ", } \\
\text { ", } \\
\text { ", }\end{array}$ & $\begin{array}{c}1875 \\
1878 \\
1879 \\
1880 \\
1885 \\
1900 \\
1900 \\
1910 \\
1925 \\
? \\
\cdots \\
\ldots \\
\ldots \\
195^{\circ}\end{array}$ & $\begin{array}{l}\text { B } \\
\text { pink } \\
\text { B } \\
\text { pink } \\
\text { B"d } \\
\text { red } \\
\text { pink } \\
\text { B } \\
\text { pink } \\
\text { red } \\
\text { pink } \\
\text { red }\end{array}$ \\
\hline
\end{tabular}

* Best 15 .

† Second 15 varieties in 1938 according to Krelage.

(fig. 2). The evidence needs and deserves re-examination but the variety seems to be lost. 
TABLE I (continued)

\begin{tabular}{|c|c|c|c|c|c|c|c|}
\hline \multicolumn{8}{|c|}{ C. UNBALANCED : HyPO-TRIPLOIDS (9 varieties) } \\
\hline \multirow{2}{*}{ Name } & \multirow{2}{*}{ Author } & \multirow{2}{*}{ Date } & \multirow{2}{*}{$2 n$} & \multicolumn{3}{|c|}{ Complement } & \multirow{2}{*}{ Colour } \\
\hline & & & & $\mathrm{L}\left(\mathrm{L}^{n}\right)$ & $\mathbf{M}$ & $\mathrm{S}\left(\mathrm{S}_{2}\right)$ & \\
\hline$\left\{\begin{array}{l}\text { Rosalie } \\
\text { Nimrod } \dagger \\
\text { Cinderella } \\
(\mathbf{C})\end{array}\right.$ & $\begin{array}{l}\text { Hair } \\
\text { D } \\
\text { Hair }\end{array}$ & $\begin{array}{l}1935 ? \\
1858 \\
?\end{array}$ & $\begin{array}{l}17 \\
19 \\
19\end{array}$ & $\mid \begin{array}{l}9(3) \\
\text { I I } \\
\text { I I }(3)\end{array}$ & $\begin{array}{l}4 \\
4 \\
4\end{array}$ & $\begin{array}{l}4(2) \\
4 \\
4(2)\end{array}$ & $\begin{array}{l}\text { pink } \\
,,\end{array}$ \\
\hline $\begin{array}{l}\text { Rosea maxima } \\
\text { van Speyk } \\
\text {LL}^{\prime} \text { Ordre Parfait }\end{array}$ & $\begin{array}{l}\text { M } \\
,,\end{array}$ & $\begin{array}{l}1866 \\
1840 \\
1874\end{array}$ & $\begin{array}{l}20 \\
21 \\
22\end{array}$ & $\begin{array}{l}10 \\
10 \\
11\end{array}$ & $\begin{array}{l}5 \\
6 \\
6\end{array}$ & $\begin{array}{l}5 \\
5 \\
5\end{array}$ & $\begin{array}{l}\text { В } \\
\text { ? }\end{array}$ \\
\hline $\begin{array}{l}\text { Imperator } \dagger \\
\text { Pres. Roosevelt } \\
\text { C.o. Haarlem * }\end{array}$ & $\begin{array}{l}\text { Hair } \\
\text { D,"H }\end{array}$ & $\begin{array}{l}\text { 1903 } \\
1905 ? \\
1893\end{array}$ & $\begin{array}{l}23 \\
23 \\
23\end{array}$ & $\begin{array}{l}\text { II } \\
\text { I } 2(3) \\
\text { I } 2(3)\end{array}$ & $\begin{array}{l}6 \\
5 \\
6\end{array}$ & $\begin{array}{l}6 \\
6(3) \\
5(2)\end{array}$ & $\begin{array}{l}\text { pink } \\
\text { pink (d) } \\
\text { yellow }\end{array}$ \\
\hline \multicolumn{8}{|c|}{ D. UNBALANCED : HyPER-TRIPLOIDS ( 6 varieties, 2 mutants) } \\
\hline $\begin{array}{l}\text { Ostara } \\
\text { Maryon (C) } \\
\text { Blue Herald } \\
\text { La Peyrouse } \\
\text { Card. Wiseman }\end{array}$ & $\begin{array}{l}\text { RH } \\
\text { Hair } \\
\text { RH } \\
\text { D } \\
\text { M }\end{array}$ & $\begin{array}{l}\ldots \\
\ldots \\
1 \dddot{8} \\
1885 \\
1881\end{array}$ & $\begin{array}{l}25 \\
25 \\
26 \\
27 \\
27 ?\end{array}$ & $\begin{array}{l}12(3) \\
12(3) \\
13 \\
14 \\
12\end{array}$ & $\begin{array}{l}7 \\
7 \\
7 \\
6 \\
8\end{array}$ & $\begin{array}{l}6(3) \\
6(3) \\
6 \\
6 \\
7\end{array}$ & $\begin{array}{c}\text { B } \\
\text { BB } \\
\text { B } \\
\text { B } \\
\text { red }\end{array}$ \\
\hline $\begin{array}{l}\text { L'Innocence * } \\
\text { mut. Mme. Sophie } \\
\text { Dr Lieber * } \\
\text { Schotel } \\
\text { Fair Ellen (C) }\end{array}$ & $\begin{array}{l}\text { D, H } \\
\text { Hair } \\
\text { RH } \\
\text { Hair } \\
\text {," }\end{array}$ & $\begin{array}{c}1863 \\
\ldots \\
1901 \\
\text { I } 863 \\
\ldots\end{array}$ & $\begin{array}{l}27 \\
27 \\
27 \\
27 \\
27\end{array}$ & \begin{tabular}{|l|}
$15(4)$ \\
I5(4) \\
15 \\
$15(3)$ \\
I5(3)
\end{tabular} & $\begin{array}{l}6 \\
6 \\
6 \\
6 \\
6\end{array}$ & $\begin{array}{l}6(3) \\
6(3) \\
6 \\
6(2) \\
6(2)\end{array}$ & $\begin{array}{c}\text { white } \\
\text { white (d) } \\
\text { B } \\
\text { B } \\
\text { B }\end{array}$ \\
\hline $\begin{array}{l}\text { Q.o. Blues } \dagger \\
\text { mut. Q.o. Whites } \\
\text { The Bride (C) }\end{array}$ & $\begin{array}{l}\text {,' } \\
\text {,' }\end{array}$ & $\begin{array}{c}1878 \\
(1908) \\
\ldots\end{array}$ & $\begin{array}{l}27 \\
27 \\
27\end{array}$ & $\begin{array}{l}\text { I5 (3) } \\
\text { I5 (3) } \\
\text { I5(3) }\end{array}$ & $\begin{array}{l}6 \\
6 \\
6\end{array}$ & $\begin{array}{l}6(2) \\
6(3) \\
6(3)\end{array}$ & $\begin{array}{c}\text { B } \\
\text { white } \\
, y\end{array}$ \\
\hline $\begin{array}{l}\text { A. Arendsen * } \\
\text { Garrick } \\
\text { La Grandesse } \dagger \\
\text { Edelweiss } \\
\text { Hoar Frost }\end{array}$ & $\begin{array}{c}\mathrm{D} \\
\mathrm{M} \\
\mathrm{M} \\
\text { Hair } \\
\text {,' }\end{array}$ & $\begin{array}{l}1875 \\
1848 \\
1863 \\
\cdots \\
\cdots\end{array}$ & $\begin{array}{l}28 \\
28 \\
28 \\
28 \\
28\end{array}$ & $\begin{array}{l}14 \\
15 \\
15 \\
15(4) \\
16(4)\end{array}$ & $\begin{array}{l}6 \\
6 \\
6 \\
6 \\
6\end{array}$ & $\begin{array}{l}8 \\
7 \\
7 \\
7(3) \\
6(3)\end{array}$ & $\begin{array}{c}\text { B"(d) } \\
\text { white } \\
, " \\
\text { ", }\end{array}$ \\
\hline \multicolumn{8}{|c|}{ E. UNBALANCED : Hypo-TETRAPLOIDS (I 5 varieties) } \\
\hline $\begin{array}{l}\text { D. o. Westminster } \dagger \\
\text { D. o. York. } \\
\text { Gen. Köhler } \\
\text { Blue Beard. } \\
\text { Hindenburg. }\end{array}$ & $\begin{array}{c}\text { RH } \\
\text { Hair } \\
\text {,, } \\
\text {,' }\end{array}$ & $\begin{array}{l}1920 \\
\ldots \\
1897 \\
1940 ? \\
1930 ?\end{array}$ & $\begin{array}{l}29 \\
29 \\
29 \\
29 \\
29\end{array}$ & $\begin{array}{l}\text { I5 } \\
\text { I5 (3) } \\
\text { I5(3) } \\
\text { I5(3) } \\
\text { I6(4) }\end{array}$ & $\begin{array}{l}7 \\
7 \\
7 \\
7 \\
7\end{array}$ & $\begin{array}{l}7 \\
7(3) \\
7(3) \\
7(3) \\
6(3)\end{array}$ & $\begin{array}{c}\text { BB } \\
\text { mauve } \\
\mathbf{B}(\mathrm{d}) \\
\mathbf{B} \\
\mathbf{B}\end{array}$ \\
\hline $\begin{array}{l}\text { Grace Darling (C) } \\
\text { Chestnut Flower } \\
\text { Delft Blue } \\
\text { Myosotis } \dagger: \\
\text { Totula }\end{array}$ & $\begin{array}{l}\text {,' } \\
\text {," } \\
\text { D’ }\end{array}$ & $\begin{array}{c}1880 \\
\ldots \\
1910 \\
\text { 1913 }\end{array}$ & $\begin{array}{l}30 \\
3 \circ \\
3 \circ \\
3 \circ \\
3 \circ\end{array}$ & $\begin{array}{l}\text { I5 (3) } \\
\text { I5(3) } \\
\text { I5(3) } \\
\text { I5(4) } \\
\text { I5 }\end{array}$ & $\begin{array}{l}8 \\
8 \\
8 \\
8 \\
7\end{array}$ & $\begin{array}{l}7(3) \\
7(3) \\
7(3) \\
7(3) \\
8\end{array}$ & $\begin{array}{c}\mathbf{B} \\
\underset{\mathbf{p i n k}}{\mathbf{B}}(\mathrm{d}) \\
\mathbf{B} \\
\mathbf{B}\end{array}$ \\
\hline $\begin{array}{l}\text { Mr Dames } \dagger \\
\text { Perle Brillante } \dagger \\
\text { Dr Stresemann } \\
\text { Winston Churchill } \\
\text { Springtime (C) }\end{array}$ & $\begin{array}{l}\text { RH } \\
\text { Hair } \\
, " \\
, " \\
\text { ", }\end{array}$ & $\begin{array}{l}1910 \\
1895 \\
1930 \\
\text { I } 945^{?} \\
\quad \cdots\end{array}$ & $\begin{array}{l}\mathbf{3}^{\mathbf{I}} \\
\mathbf{3}^{\mathbf{I}} \\
\mathbf{3 I}^{\mathbf{I}} \\
\mathbf{3}^{\mathbf{I}} \\
\mathbf{3}^{\mathbf{I}}\end{array}$ & $\begin{array}{l}16 \\
16(4) \\
16(4) \\
16(4) \\
16(4)\end{array}$ & $\begin{array}{l}8 \\
8 \\
8 \\
8 \\
8\end{array}$ & $\begin{array}{l}7 \\
7(3) \\
7(4) \\
7(4) \\
7(4)\end{array}$ & $\begin{array}{l}\text { pink } \\
\text { B } \\
\text { B } \\
\text { B } \\
\text { B }\end{array}$ \\
\hline
\end{tabular}


(iii) Dr Stresemann is described in Van Tubergen's catalogue of I936-37 as "a greatly improved Queen of the Blues." Since it has gained four chromosomes we may take this as a figure of speech. It is no doubt a seedling, not a bud sport. Winston Churchill seems to be its post-war synonym.

\section{BALANCE IN THE UNBALANCED VARIETIES}

We know a great deal about the distributions of chromosomes varying in total number in the gametes and zygotes produced by polyploids. We know very little, however, about how particular types of chromosomes vary. Their distributions have been accurately studied in the pollen grains of triploid hyacinths by Darlington and Mather (1944). We showed that unbalanced multiples of the chroniosome set were as satisfactory, or nearly so, as the balanced multiples, thus indicating that each chromosome was internally balanced to an unusual extent. Yet the different types of chromosome such as $\mathbf{M}$ and $\mathrm{S}$ still showed (by a correlation in frequency) some dependence on one another.

We want now to carry this study further with the varieties themselves. The commercial varieties have been selected for vitality and so should give us an indication of what balances or combinations are favoured in the body cells as a permanent basis of growth.

The diploid and triploid varieties of course tell us nothing new. The intermediate unbalanced varieties on the other hand are something unprecedented among cultivated plants. The existence of such a range of unbalanced numbers in successful clones indicates that variations of number arising somatically might well maintain themselves. Differences of number in different determinations of the same variety are therefore no doubt sometimes valid. Changes of number should sometimes be associated with phenotypic mutations or divergences from description as indeed they appear to be in the suggested origin of Marconi and of Madame du Barry.

Now the unbalanced varieties have been selected in competition with the balanced varieties by breeders who were, of course, quite unaware of what they were selecting. What advantage can they have? Merely, it would seem, the choice of new balances that they offer. This choice, if it is effective should give a non-random sample of the population as opposed to the random sample of chromosome combinations expected from breeding the triploid varieties which must usually or originally have been their parents.

When the $\mathrm{L}$ chromosomes are considered in number relation with $\mathrm{M}$ and $\mathrm{S}$ in the varieties we find an obvious correlation in the whole range from diploid and tetraploid. When, however, the square is divided into four it is seen at once that the correlation depends partly on the exclusion of the $4: 2$ and $2: 4$ types of unbalance found in two of the quarters. The other two quarters where the 
limits of unbalance are $3: 2$ and $4: 3$ are, however, far from evenly filled. It is not so much that they show any general correlation as that certain combinations are overwhelmingly preferred (fig. 3 ).

What does this preference depend on? To find out we must examine the detailed relationships of the chromosomes. Darlington and Mather noticed a preference for even numbers of $\mathrm{M}$ chromosomes in the nine varieties they considered. With the 36 varieties we now have this preference is confirmed. But the preference of $S$ and $L$ chromosomes for odd numbers is almost as striking (table 2A). The

TABLE 2A

Frequencies of chromosomes of each type in 36 unbalanced varieties (omitting 4 synonyms, from table $I c, d$ and $e$ )

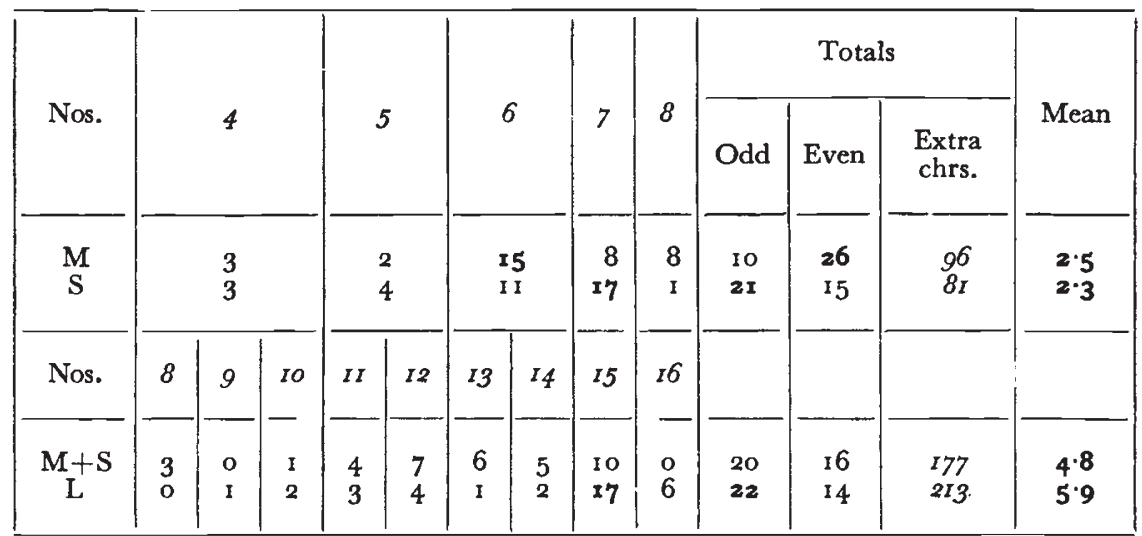

frequency of $\mathrm{M}$ and $\mathrm{S}$ chromosomes is the same but they are differently distributed. They are also correlated (table 2B).

The relations of the two types of $\mathrm{L}$ chromosome, again, indicates non-randomness. There is a great concentration at the level of ${ }_{15} \mathrm{~L}+\mathrm{L}^{n}$ chromosomes. There is also an avoidance of the $4 \mathrm{~L}^{n}$ type. This is not the first indication we have of a disadvantage in an increase of nucleolar organisers with polyploidy. Paris quadrifolia which is an undoubted tetraploid, has two, not four, nucleolar organisers. Moreover, since the substances organised in nucleoli and in the heterochromatin are similar it is interesting to notice a relationship with the decrease of heterochromatin in polyploid species of the Paris-Trillium group (Darlington, I94I).

So far as their external relations are concerned the $\mathrm{L}$ chromosomes are more numerous than $\mathrm{M}$ and $\mathrm{S}$ combined. (table 2A). The reason for this might lie in the more frequent loss of $\mathrm{M}$ and $\mathrm{S}$ chromosomes at meiosis : its source would then be mechanical rather than selective. The failure to produce a complete tetraploid itself can, however, scarcely arise from this loss : $4 \mathrm{M}$ and ${ }_{4} \mathrm{~S}$ chromosomes have not yet appeared in the same plant but, as we shall see, the necessary germ cells are produced. 
In general, the evidence suggests that the uneven distribution of chromosome complements is due to a selective concentration on certain types rather than to accident or drift.

TABLE $2 B$

Correlation or selective concentration of extra $\mathrm{M}$ and $\mathrm{S}$ chromosomes in 36 unbalanced varieties (from table $\mathrm{rc}, d$ and $e$ )

\begin{tabular}{|c|c|c|c|c|c|}
\hline 4 & & & $x$ & 1 & 0 \\
\hline 3 & & & 3 & 4 & 9 \\
\hline 2 & 0 & 1 & $\times$ & 3 & 0 \\
\hline $\mathrm{I}$ & 0 & 1 & 3 & & \\
\hline $\mathrm{S} / \mathrm{M}$ & 0 & $\mathrm{I}$ & 2 & 3 & 4 \\
\hline
\end{tabular}

TABLE 2C

Combinations of $\mathrm{L}$ and $\mathrm{L}^{n}$ chromosomes determined in 22 unbalanced varieties (from table $i c, d$ and $e$ )

\begin{tabular}{|c|c|c|c|c|c|c|c|c|c|c|}
\hline \multicolumn{2}{|l|}{$\mathbf{L}^{n}$} & 6 & 7 & 8 & 9 & 10 & II & 12 & Total & $\begin{array}{l}\text { Extra } \\
\text { chrs. }\end{array}$ \\
\hline \multirow[b]{4}{*}{ Total } & 2 & $\ldots$ & $\ldots$ & $\ldots$ & $\ldots$ & $x$ & $X$ & $X$ & $o$ & 0 \\
\hline & 3 & I & $\ldots$ & I & 3 & $\ldots$ & $\ldots$ & 9 & 14 & 14 \\
\hline & 4 & $x$ & $X$ & $x$ & $\ldots$ & $\ldots$ & 3 & 5 & 8 & 16 \\
\hline & . & $I$ & $o$ & $I$ & 3 & $o$ & 3 & 14 & 22 & 30 \\
\hline \multicolumn{2}{|c|}{ Extra chrs. } & 0 & o & 2 & 9 & 0 & 15 & 84 & I Io & $\ldots$ \\
\hline
\end{tabular}

Mean extra chromosomes per variety : $\mathrm{L}-5 \cdot 00, \mathrm{~L}^{n}-1 \cdot 36$.

$X$ : types impossible within the limits of balance shown by fig. 3 . 


\section{THE EFFECTS OF SELECTION}

\section{(i) Historical change}

If we examine the times of origin of varieties with different numbers we see that the highest numbers seem to have arisen only in recent years (table I and fig. 3). This can hardly be due to the high-number group being short-lived, for nearly all recent varieties belong to this group.

We can assume that the universal habit of plant breeders of breeding from the best has been followed. In most plants where the best are triploids the practice is disastrous. In the hyacinths, on the other hand, it has evidently been successful. We may therefore imagine the following steps :-
(i) $2 x \times 2 x \rightarrow 2 x($ I $550-1850)$
(ii) $2 x \times 2 x \longrightarrow 3 x$ ( $1700-1900)$
(iii) $2 x \times 3 x \longrightarrow 2-3 x(1800-1920)$
(iv) $3 x \times 3 x \longrightarrow 2-4 x$ (1850-1920)
(v) $3-4 x \times 3-4 x \rightarrow$ nearly $4^{x}$ (190o-1950)

This history is sharply contrasted with that of the tulips and daffodils. Indeed, it differs from that of any other known cultivated plant in its easy transition. It does so owing to the fact that in the hyacinth all viable numbers, if not all combinations, of chromosomes have so far proved fertile.

\section{(ii) Present-day varieties}

We can now interpret the historical development of the hyacinth in relation to general horticultural value. Take, for example, the important varieties in cultivation in Holland in 1938 from Krelage's list (table 3 ). Of the 36 varieties given by Krelage, 3 are bud sports,

TABLE 3

Distribution of chromosome numbers in hyacinths according to the area cultivated in $193^{8}$ (from tables $I$ and 4 , cf. fig. 2 and from Krelage, 1946, p. 636)

\begin{tabular}{|c|c|c|c|c|c|}
\hline & $2 x$ & $17-23$ & $3^{x}$ & $25-28$ & $29-3^{1}$ \\
\hline First $15_{15}:$ & $\begin{array}{l}4 \\
5\end{array}$ & $\begin{array}{l}1 \\
2\end{array}$ & $\begin{array}{l}6 \\
2\end{array}$ & $\begin{array}{l}4 \\
3\end{array}$ & $\begin{array}{l}0 \\
3\end{array}$ \\
\hline Total best varieties : 30 & 9 & 3 & 8 & 7 & 3 \\
\hline Outsiders counted : 57 & 23 & 5 & 8 & 9 & 12 \\
\hline
\end{tabular}

and 3 are unknown for number. The remaining 30 may be compared with the 57 varieties not mentioned by Krelage but whose chromosome numbers have been counted as in table 3 and fig. 3 .

The 57 outsiders include both extremes: many of the older 
diploids have dropped out of the first rank in cultivation. The newer varieties with 29,30 and 31 chromosomes on the other hand, have not yet reached this rank.

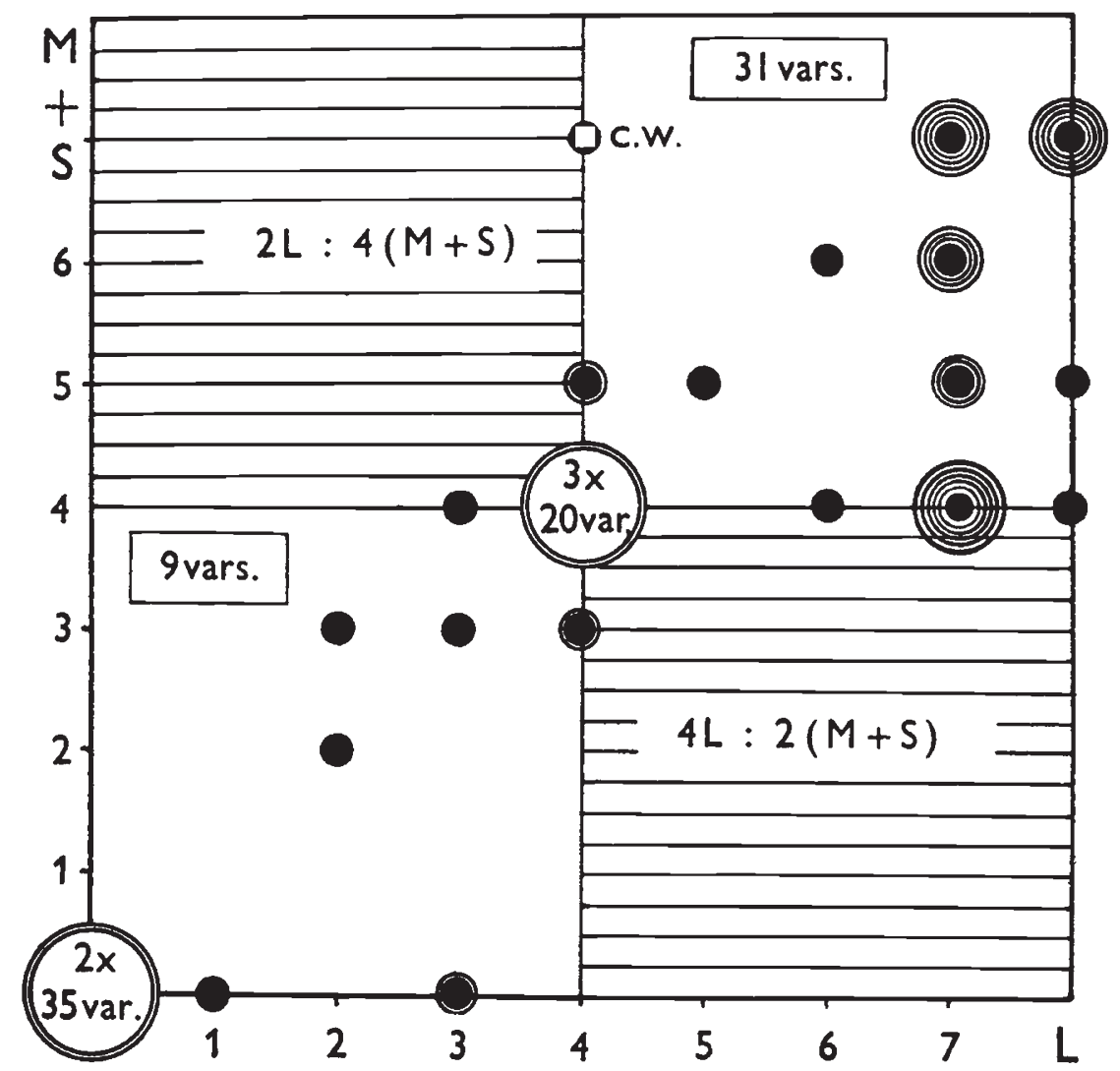

Frg. 2.-Graph showing the relations of $\mathrm{L}$ to $\mathrm{M}+\mathrm{S}$ in the extra chromosomes of hyacinth varieties. C.W. : the dubious Cardinal Wiseman.

(iii) Colour and chromosome number

So far as we can see, any colour can be obtained with any chromosome number. But in fact the frequencies of colours change, and change in a very regular way, with chromosome number (table 4). Again there is a selective concentration. Among diploids the predominant colour is red, the proportion of blues being only 15 per cent. This proportion increases steadily to 80 per cent. in the highest group, that with more than 29 chromosomes. A possible explanation which suggests itself is the following :-

The higher chromosome numbers being the more recent, blue varieties have been introduced more than other colours in recent years (whether on account of fashion or of greater vigour, as Hibberd suggested) and thus have come to be associated with the higher 


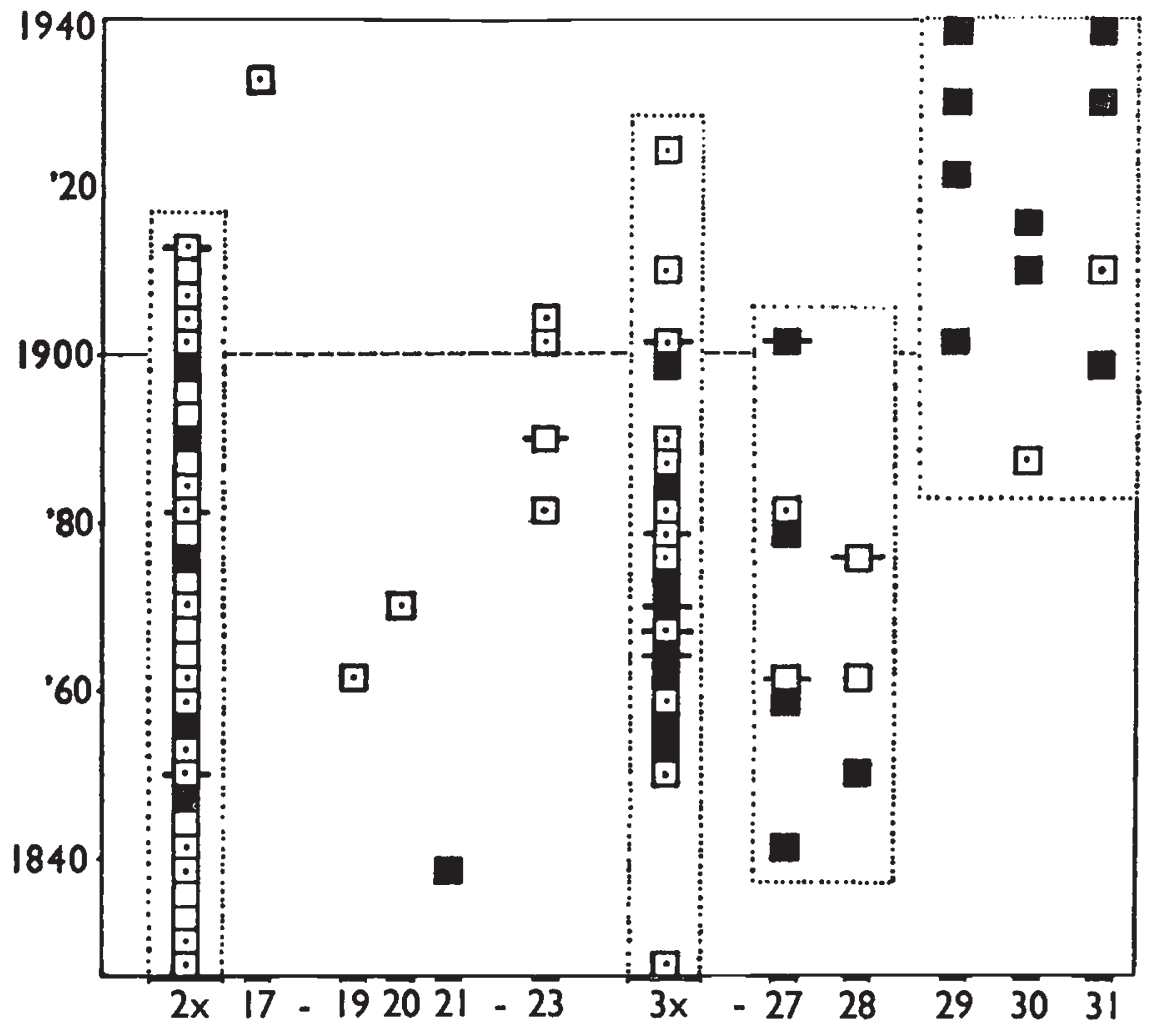

FIG. 3. - The chromosome numbers of hyacinth varieties (seedlings, not mutants) shown, in relation to their colours, date of introduction and economic value. Blue is solid, red dotted, other colours white. Included in the best 15 varieties in 1938, from Krelage's list, winged.

TABLE 4

Colours of varieties and their colour-changed mutants (when known) arranged by chromosome number (from Table I).

In brackets are the varieties introduced since 1900

\begin{tabular}{|c|c|c|c|c|c|c|c|}
\hline & $A: 2 x$ & $C: 17-23$ & $B: 3 x$ & $D: 25-28$ & $E: 29-31$ & Total & $\begin{array}{c}\text { Total } \\
\text { since } \\
\text { I goo }\end{array}$ \\
\hline $\begin{array}{l}\text { White } \\
\text { B and BB } \\
\text { Lilac } \\
\text { Red and pink } \\
\text { Salmon } \\
\text { Yellow }\end{array}$ & $\begin{array}{r}2 \\
5(1) \\
3 \\
17(4) \\
3 \\
3(1)\end{array}$ & $\begin{array}{l}\cdots \\
1 \cdots \\
6 \stackrel{(2)}{\cdots} \\
1\end{array}$ & $\begin{array}{c}\dddot{9} \\
9(1) \\
2 \\
16(3) \\
\ldots \\
\ldots\end{array}$ & $\begin{array}{l}7 \\
9(1) \\
\cdots \\
1 \\
\cdots \\
\cdots\end{array}$ & $\begin{array}{l}120 \\
12(7) \\
2(1) \\
\cdots \\
\cdots\end{array}$ & $\begin{array}{r}9 \\
36 \\
6 \\
42 \\
3 \\
4\end{array}$ & $\begin{array}{l}\cdots \\
10 \\
\cdots \\
\text { 10 } \\
\cdots \\
\text { I }\end{array}$ \\
\hline Total . & 33 & 8 & 27 & 17 & 15 & 100 & 21 \\
\hline Blue/Total . & $15.3 \%$ & $12 \cdot 5 \%$ & $33 \cdot 3 \%$ & $52 \cdot 9 \%$ & $80 \cdot 0 \%$ & & $\%$ \\
\hline $\begin{array}{l}\text { Blue/Total since } \\
1900\end{array}$ & $16 \cdot 6 \%$ & ... & $25 \%$ & $\ldots$ & $87.5 \%$ & & $\%$ \\
\hline
\end{tabular}


numbers. But in fact, as table 4 shows, the proportion of blue varieties introduced has not increased since Igoo.

Thus we are driven (failing any other solution) to the extraordinary conclusion that the mutant (non-blue) colours are less compatible with the raised chromosome numbers required by the selection of breeders, than is the wild type colour. In other words, the explanation of the greater vigour of the blue varieties pointed out by Hibberd is an inherent physiological property of the blue gene not in an absolute sense but in relation to chromosome number.

\section{(iv) Leaf number}

A secondary but not uninteresting feature of selection in hyacinths is the leaf number. St Simon pointed out what the earlier illustrations

TABLE 5

Variation in leaf number of first size bulbs of hyacinth varieties from Messrs Suttons trials (6th April 1950) *

\begin{tabular}{|c|c|c|c|c|c|c|c|c|c|}
\hline \multirow{2}{*}{ Variety } & \multirow{2}{*}{ 2n } & \multicolumn{5}{|c|}{ Leaf number } & \multirow{2}{*}{ Total } & \multirow{2}{*}{$\mathbf{n}$} & \multirow{2}{*}{$\mathbf{M}$} \\
\hline & & 7 & 8 & 9 & 10 & II & & & \\
\hline $\begin{array}{l}\text { Pink Pearl } \\
\text { La Victoire } \\
\text { Lord Balfour : }\end{array}$ & $\begin{array}{l}16 \\
16 \\
16\end{array}$ & $\begin{array}{r}\cdots \\
\mathbf{I} \\
\cdots\end{array}$ & $\begin{array}{r}11 \\
5 \\
\ldots\end{array}$ & $\begin{array}{l}2 \\
3 \\
3\end{array}$ & $\begin{array}{l}1 \\
1 \\
4\end{array}$ & $\begin{array}{l}\cdots \\
\cdots \\
\cdots\end{array}$ & $\begin{array}{r}116 \\
84 \\
67\end{array}$ & $\begin{array}{r}14 \\
10 \\
7\end{array}$ & $\begin{array}{l}8 \cdot 3 \\
8 \cdot 4 \\
9 \cdot 5\end{array}$ \\
\hline All $2 x$ & & I & 16 & 8 & 6 & $\ldots$ & 267 & $3^{I}$ & 8.6 \\
\hline $\begin{array}{l}\text { Bismarck } \\
\text { King of the Blues and }\end{array}$ & $\begin{array}{l}24 \\
24\end{array}$ & I & $\ldots$ & $\begin{array}{r}1 \\
17\end{array}$ & 4 & $\begin{array}{l}\ldots \\
\ldots\end{array}$ & $\begin{array}{r}57 \\
392\end{array}$ & $\begin{array}{r}7 \\
46\end{array}$ & $\begin{array}{l}8 \cdot 1 \\
8 \cdot 5\end{array}$ \\
\hline $\begin{array}{r}\text { mutants } \\
\text { Lady Derby }\end{array}$ & 24 & I & 6 & 10 & 7 & $\ldots$ & $r_{55}$ & 18 & $8 \cdot 6$ \\
\hline Jan Bos & 24 & $\cdots$ & $\cdots$ & 3 & 2 & 4 & $9 I$ & 9 & $10 \cdot 6$ \\
\hline All $3 x$ & $\ldots$ & 2 & 35 & $3^{I}$ & 7 & 4 & 695 & 80 & $8 \cdot 7$ \\
\hline Queen of the Blues & 27 & 2 & 3 & $\ldots$ & $\ldots$ & $\ldots$ & 38 & 5 & $7 \cdot 6$ \\
\hline$\widetilde{L}$ 'Innocence & 27 & 14 & 12 & 4 & $\ldots$ & $\ldots$ & 230 & 30 & $7 \cdot 7$ \\
\hline Dr Lieber & 27 & 5 & 2 & $\cdots$ & $\cdots$ & $\cdots$ & $5^{8}$ & 7 & $8 \cdot 3$ \\
\hline Myosotis . & 30 & 3 & 8 & I & $\ldots$ & $\cdots$ & 94 & 12 & $7 \cdot \overline{8}$ \\
\hline Dr Stresemann . & $3^{I}$ & 2 & 8 & 2 & $\ldots$ & $\ldots$ & 96 & 12 & $8 \cdot 0$ \\
\hline Perle Brillante. & $3^{I}$ & 4 & 4 & $\ldots$ & $\ldots$ & $\ldots$ & 60 & 8 & $7 \cdot 5$ \\
\hline All $3 x+$ & $\cdots$ & 29 & $3^{6} \ldots$ & 7 & $\cdots$ & $\cdots$ & 576 & 74 & $7 \cdot 8$ \\
\hline
\end{tabular}

confirm, namely, that the commonest leaf number in flowering hyacinths in early times was six. Modern hyacinths of full size,

* We are much indebted to Mr A. P. Balfour and his colleagues for helping us to make these records. 
however, have an average of about eight and a maximum leaf number of eleven is reached in one triploid, Fan Bos. Second size bulbs have from 0.4 to $\mathrm{I} \cdot 2$ leaves less. The unbalanced varieties with the largest flowers which have been raised in the last century seem to have slightly fewer leaves than the old balanced varieties (table 5). The five double varieties we have had in cultivation in 1951 -two triploid and three hypertriploid-had 1 i5 leaves on 17 bulbs, an average of $6 \cdot 8$, lower that is, than any single-flowered variety.

\section{POLLEN GRAINS OF THE NEAR-TETRAPLOIDS}

The extensive counts of pollen grain mitoses of triploids carried out by earlier workers have shown an almost complete absence of abnormality. The consequences of crossing-over in inversions so

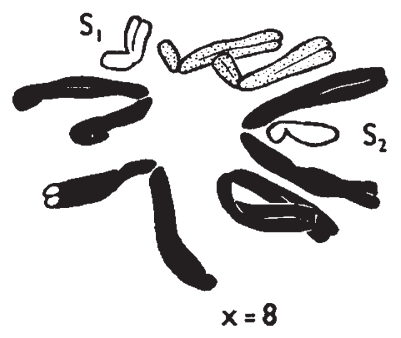

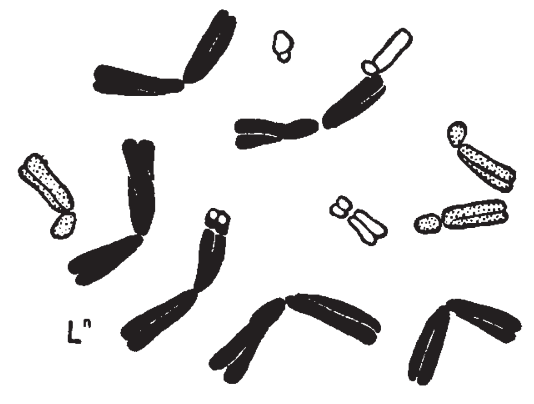

$x+4=12$

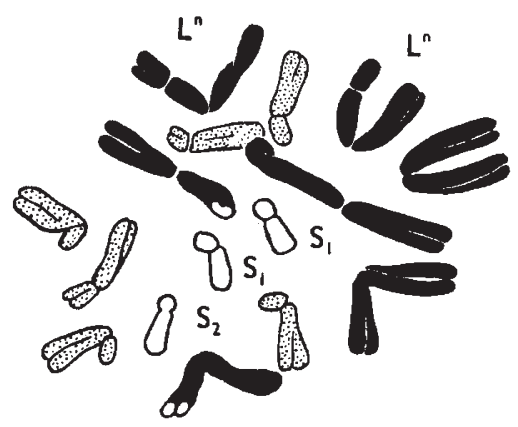

$2 x-L+M M-S_{2}=16$

Fig. 4.-Proportionate complements at pollen grain mitosis. Above, a haploid set in Anne Marie. Left, $6: 3: 3$ complement from Duke of Westminster. Right, a complement with balanced diploid number but unbalanced types resulting from chromatid nondisjunction in Duke of Westminster. Acetic-alcohol-Feulgen preparations. $\quad \times 1500$.

freely found in triploid tulips (Upcott, 1939) or daffodils (Wylie, 1949) rarely appear in hyacinths, whose stability in this respect exceeds what is needed to account for the stability of the chromosomes in the varieties. The problem is, therefore, merely one of individual distribution. 
Our observations of the pollen grains have been limited to from $5^{6}$ to 124 mitoses in 15 of the triploid and hyper-triploid varieties we have studied (tables 6 and 7). These numbers do not allow of the statistically valid inference of chromosome interactions. They show, however, that the distributions follow the principles laid down by Darlington and Mather, viz.: an increasing frequency of loss with decreasing size of the chromosome. All our counts, however, show less loss than the previous counts of triploids-even our own triploid. In the near-tetraploids, quadrivalents must be subject to less loss than trivalents.

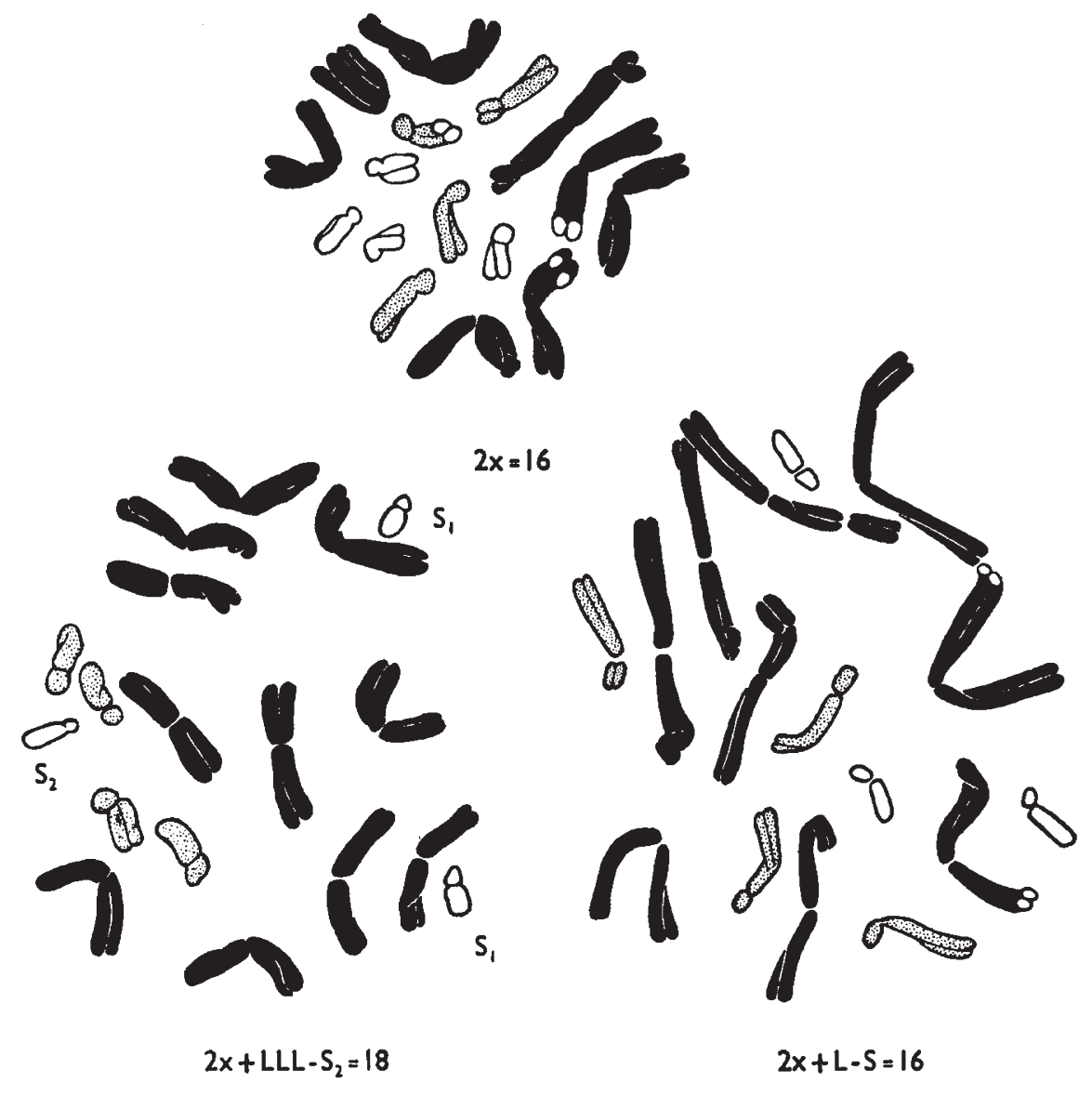

Frg. 5.-Three pollen grain mitoses of $M r$ Dames with balanced diploid, unbalanced diploid and hyperdiploid numbers. $\times \mathrm{I}_{500}$.

Pollen grains with more than the diploid total number were found in the near-tetraploid varieties. On the other hand, chromosome complements with more than the diploid number for one chromosome type and less for another (i.e. in $3: \mathrm{I}$ unbalance) were common (figs. 4 and 5). 
It might be argued that these suggest the possibility of such an unbalance in the somatic complement of a variety. But there is a difference between carrying out a single pollen grain mitosis (which is possible for an under-haploid nucleus, $c f$. Conger, 1940) and maintaining the whole sequence of development and the efficiency

\section{TABLE 6}

Counts of pollen-grain mitoses in hyacinth varieties showing the distribution and loss of extra chromosomes (1948)

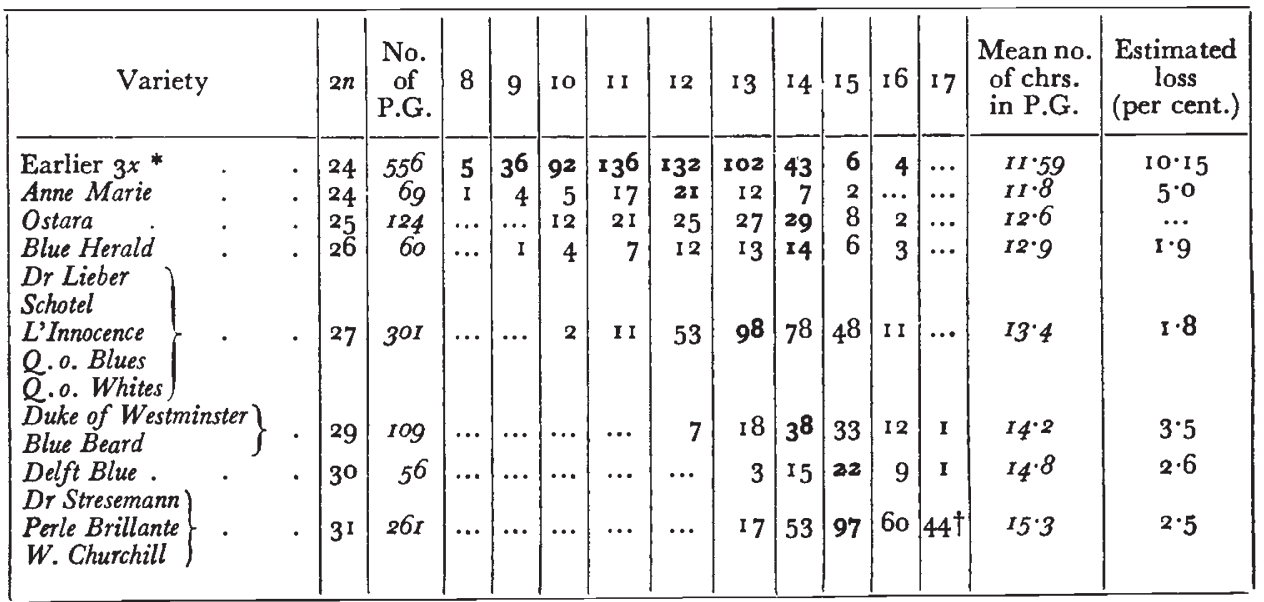

* Belling, I 924 ; Darlington, I926; Darlington and Mather, r 944 .

$\dagger$ Including three with 18 and one with 19 .

TABLE 7

Variation in numbers of chromosomes of each type in the pollen grains of $3^{x}$ and aneuploid varieties. Numbers beyond the disomic number in italics (part of data in table 6)

\begin{tabular}{|c|c|c|c|c|c|c|c|c|c|c|c|c|c|c|c|c|c|c|c|}
\hline & \multicolumn{9}{|c|}{$\mathrm{L}$} & \multicolumn{6}{|c|}{$\mathbf{M}$} & \multicolumn{4}{|c|}{$\mathbf{S}$} \\
\hline & $2 n+$ & 4 & 5 & 6 & 7 & 8 & 9 & IO & II & $2 n+$ & 2 & 3 & 4 & 5 & 6 & $2 n+$ & 2 & 3 & 4 \\
\hline 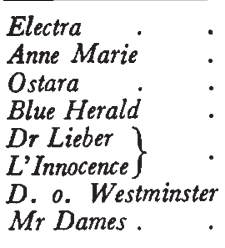 & $\begin{array}{l}(4) \\
(4) \\
(4) \\
(5) \\
(7) \\
(7) \\
(8)\end{array}$ & $\begin{array}{r}13 \\
3 \\
2 \\
2 \\
\ldots \\
\ldots \\
\cdots\end{array}$ & $\begin{array}{r}42 \\
\text { I } 5 \\
\text { I } 5 \\
\text { I I } \\
3 \\
I \\
\ldots\end{array}$ & $\begin{array}{r}5^{8} \\
29 \\
22 \\
19 \\
15 \\
7 \\
1\end{array}$ & $\mid \begin{array}{r}50 \\
20 \\
15 \\
18 \\
50 \\
23 \\
9\end{array}$ & $\begin{array}{r}12 \\
2 \\
9 \\
8 \\
40 \\
21 \\
17\end{array}$ & $\begin{array}{r}\ldots \\
\ldots \\
\ldots \\
2 \\
2 \\
4 \\
2 I\end{array}$ & $\begin{array}{c}\ldots \\
\cdots \\
\cdots \\
\cdots \\
\ldots \\
x \\
2\end{array}$ & $\begin{array}{c}\cdots \\
\cdots \\
\cdots \\
\cdots \\
\cdots \\
\ldots \\
I\end{array}$ & $\begin{array}{l}(2) \\
(2) \\
(3) \\
(3) \\
(2) \\
(3) \\
(4)\end{array}$ & $\begin{array}{r}70 \\
21 \\
1 \\
3 \\
33 \\
\ldots \\
1\end{array}$ & $\begin{array}{r}60 \\
27 \\
3 x \\
29 \\
5 \\
24 \\
7\end{array}$ & $\begin{array}{l}45 \\
21 \\
30 \\
27 \\
33 \\
29 \\
3^{8}\end{array}$ & $\begin{array}{c}\cdots \\
\cdots \\
I \\
I \\
\cdots \\
3 \\
5\end{array}$ & $\begin{array}{c}\cdots \\
\cdots \\
\cdots \\
\cdots \\
\cdots \\
x \\
\cdots\end{array}$ & $\begin{array}{l}(2) \\
(2) \\
(2) \\
(2) \\
(2) \\
(3) \\
(3)\end{array}$ & $\begin{array}{r}85 \\
29 \\
30 \\
17 \\
42 \\
7 \\
4\end{array}$ & $\begin{array}{l}63 \\
25 \\
24 \\
24 \\
46 \\
3^{2} \\
3^{2}\end{array}$ & $\begin{array}{r}27 \\
15 \\
9 \\
19 \\
29 \\
18 \\
15\end{array}$ \\
\hline
\end{tabular}

of protein production in the body of the plant. These mitoses are interesting, however, in other ways. They show that in other plants, where the types are not distinguishable, a balanced chromosome number may conceal a genuine unbalance.

Unbalanced pollen grains are also interesting in showing extreme abnormalities in the segregation of multivalents, e.g. the pollen grain 
of Duke of Westminster (15:7:7) which had $7: 6: 3$ chromosomes (fig. 5 and tables 6 and 7 ). Here there must have been $\mathrm{I} \mathrm{M}^{\mathrm{iv}}+\mathrm{I} \mathrm{M}^{\mathrm{iii}}$ at meiosis and of these seven chromosomes, or more strictly fourteen chromatids, six entered one pollen grain. Such an inequality can have arisen quite simply in this way: one $\mathrm{M}$ univalent might be included double or undivided to give two chromosomes in one nucleus. Two trivalents might then divide into $2+\mathrm{r}$. Thus a nucleus might have a legitimate segregation of four, together with an illegitimate inclusion of two, chromosomes. The complete tetrad would then

TABLE 8

Summary of table 7

\begin{tabular}{|c|c|c|c|c|c|c|c|}
\hline \multirow{3}{*}{ Type } & \multirow{3}{*}{$\begin{array}{c}\text { No. of } \\
\text { varieties }\end{array}$} & \multirow{3}{*}{$\begin{array}{l}\text { No. of } \\
\text { cells }\end{array}$} & \multicolumn{3}{|c|}{ Extra chromosomes } & \multirow{3}{*}{$\begin{array}{l}\text { Proportion } \\
\text { realised }\end{array}$} & \multirow{3}{*}{$\begin{array}{c}\text { No. of } \\
\text { chromosomes }\end{array}$} \\
\hline & & & \multirow{2}{*}{ Somatic } & \multicolumn{2}{|c|}{ Pollen grain } & & \\
\hline & & & & $\begin{array}{c}\text { Mean } \\
\text { expected }\end{array}$ & $\begin{array}{c}\text { Mean } \\
\text { observed }\end{array}$ & & \\
\hline L & $\begin{array}{l}3 \\
1 \\
3 \\
1\end{array}$ & $\begin{array}{r}307 \\
60 \\
174 \\
51\end{array}$ & $\begin{array}{l}4 \\
5 \\
7 \\
8\end{array}$ & $\begin{array}{l}2 \cdot 0 \\
2 \cdot 5 \\
3 \cdot 5 \\
4 \cdot 0\end{array}$ & $\begin{array}{l}2 \cdot 075 \\
2 \cdot 417 \\
3 \cdot 345 \\
3 \cdot 941\end{array}$ & $\begin{array}{l}\text { I.04 } \\
0.97 \\
0.96 \\
0.99\end{array}$ & $\begin{array}{l}614 \\
150 \\
608 \\
204\end{array}$ \\
\hline $\mathbf{M}$ & $\begin{array}{l}4 \\
3 \\
\mathrm{I}\end{array}$ & $\begin{array}{r}36 \mathrm{I} \\
\mathrm{I} 8 \mathrm{o} \\
5 \mathrm{I}\end{array}$ & $\begin{array}{l}2 \\
3 \\
4\end{array}$ & $\begin{array}{l}I \cdot 0 \\
I \cdot 5 \\
2 \cdot 0\end{array}$ & $\begin{array}{l}0.93 \mathrm{I} \\
\mathrm{I} \cdot 528 \\
\mathrm{I} \cdot 92 \mathrm{I}\end{array}$ & $\begin{array}{l}0.93 \\
1.02 \\
0.96\end{array}$ & $\begin{array}{l}36 \mathrm{I} \\
270 \\
102\end{array}$ \\
\hline $\mathbf{S}$ & $\begin{array}{l}6 \\
2\end{array}$ & $\begin{array}{l}484 \\
\text { I08 }\end{array}$ & $\begin{array}{l}2 \\
3\end{array}$ & $\begin{array}{l}1 \cdot 0 \\
1 \cdot 5\end{array}$ & $\begin{array}{l}0 \cdot 787 \\
\mathrm{I} \cdot 204\end{array}$ & $\begin{array}{l}0.79 \\
0.80\end{array}$ & $\begin{array}{l}4^{8}{ }^{8} \\
162\end{array}$ \\
\hline
\end{tabular}

have the constitution in respect of $M$ chromosomes : $6+4+2+2=14$. The conditions for this inequality of distribution are found at meiosis in aneuploid hyacinths (Darlington, I929). It is also to be noted that this extreme inter-type unbalance is found in respect of the $M$ chromosomes which, as we saw earlier, may well have a mutually dependent or intra-type balance.

The finding of genuinely balanced diploid pollen grains shows that in the course of breeding the modern varieties with 30 and 31 chromosomes true tetraploid seedlings must often have been raised. They must have been rejected as commercial varieties. Perhaps the mechanical limit to the number of chromosomes which can be conveniently accommodated in the cells available has been reachedfor the time being.

\section{SUMMARY}

I. The garden hyacinths have been selected for increase in size and chromosome number and for variety of colour since they were introduced to Europe in 1560. 
Microphotographs of root-tip mitoses in varieties of hyacinths, pre-treated with mono bromonaphthalene and Feulgen stained. $\times 1600$.

I. Distinction, mutant cell in the normal diploid : $2 n=16$.

In this cell the $\mathrm{L}^{n}$ chromosome at 9 o'clock has gained in its distal segment probably by interchange with another chromosome : the only aberrant cell seen in our studies.

2. Scarlet O'Hara, alias Madame du Barry : bud sport of Distinction : $2 \mathrm{n}=\mathrm{I} 6$, one $\mathbf{L}$ deficient : the reciprocal condition to that shown above but characteristic of the whole clone.

3. Rosalie : $2 \mathrm{n}=17 ; 3 \mathrm{~L}^{n}$ chromosomes show their nucleolar constrictions. 


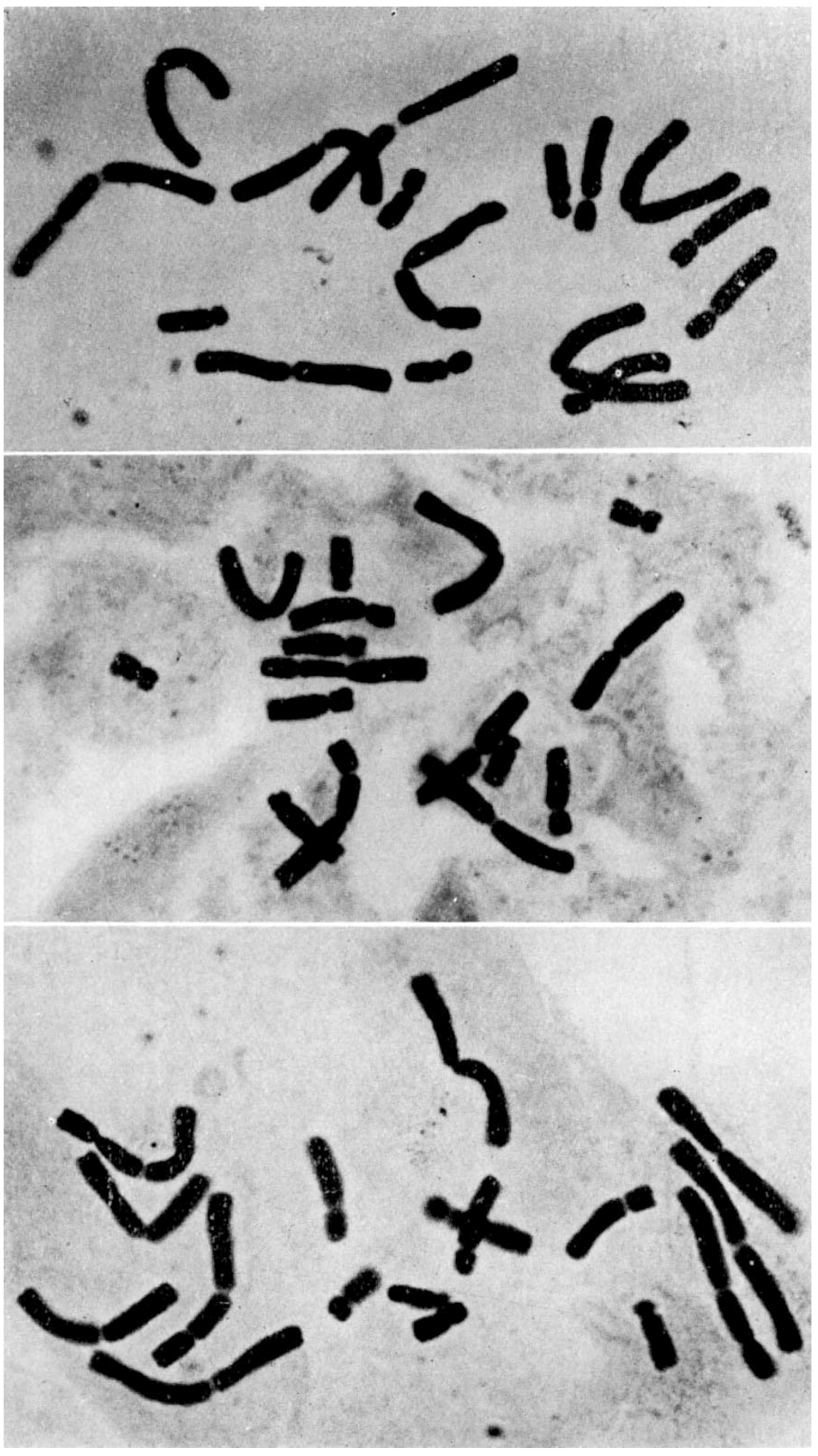


2. In the haploid set of eight there are five distinct chromosome types. Among over 2000 chromosomes recorded in 106 varieties only four have been of abnormal shape. This uniformity agrees with the documentary evidence in pointing to a highly homogeneous origin.

3. The 106 varieties are constituted as follows :-

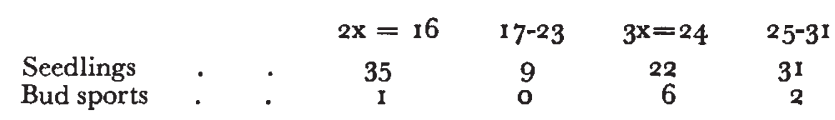

The occurrence of such a series of unbalanced combinations is unique among all plants and animals.

4. The loss of chromosomes at meiosis is highest for the short type, lowest for the long, in the unbalanced as well as in the triploid varieties.

5. The limits of unbalance are strictly set and ascertainable since 5 chromosome types are recognisable. Although pollen grains can have a $3:$ I unbalance, the $4: 2$ unbalance does not occur somatically, and varieties are limited to $4: 3$ and $3: 2$. There is also strong selective concentration on certain types of unbalance.

6 . The selection of the varieties rather than of their parental gametes is responsible even for the notable absence of the balanced tetraploid combination.

7. Blue has been progressively more favoured at the expense of other flower colours as the chromosome number has been raised by selection during the last 100 years. Its advantage, noted in 1880 , has been due to physiology, not to fashion.

8. Of the 5000 garden hyacinths raised, less than Ioo varieties are known to survive. Additions to this number would (we have tried to show) be a gain to science.

\section{REFERENCES}

BARNAART, A. E. I889. Historical notes on Dutch hyacinths. F. roy Hort. Soc., $I I, 49-54$.

BELLING, J. 1924. Distribution of chromosomes in the pollen grains of the triploid hyacinth. Amer. Nat., 58, 440-446.

CONGER, A. D. 1940. Chromosome deficiencies in microspores of Tradescantia. 7. Hered., 3I, 339-34I.

Darlington, c. D. 1926. Chromosome studies in the Scillex. F. Genet., 16, 237-251.

DARLINGTON, G. D. 1929. Meiosis in polyploids. II. Aneuploid hyacinths. $\mathcal{F}$. Genet., 2I, 17-56.

DARLINGTON, c. D. 1933. The origin and behaviour of chiasmata. VI. Hyacinthus amethystinus. Biol. Bull., 63, 368-71.

DARLington, c. D. 1941. Polyploidy, crossing-over and heterochromatin in Paris. Ann. Bot., n.s. 5, 203-216.

DARLINGTON, C. D., AND MATHER, K. 1944. Chromosome balance and interaction in Hyacinthus. 7. Genet., $46,52-61$.

HIBbERD, s. 1880 . The hyacinth and the amaryllis. F. roy. Hort. Soc., 6, I-5. 
Kersten, J. H. 1889. The cultivation of the hyacinth in Holland. F. roy. Hort. Soc., $I I, 54-63$.

KRELAGE, E. H. 1946. Drie Eeuwen Bloembollenexport. Hague, 791 pp.

DE MOL, W. E. 192I. De l'existence de variétés hétéroploides de l'Hyacinthus orientalis

L. dans les cultures hollandaises. Arch. neerl. Sci., IIIB, 4, i 8-I I 7.

st simon, H. DE. I768. Des Jacintes. Amsterdam (cf. Gardns.' Chron., 32, 377, I897). srow, I. I 930. Giant pollen grains of the Hyacinthus orientalis. Cytologia, $I, 4^{1}$ 7-439. UPCoTT, M. B. 1937. Spontaneous chromosome changes in pollen grains. Nature, I39, 153 .

UPCoTT, M. B. 1939. The genetic structure of Tulipa. III. Meiosis in polyploids. 7. Genet., 37, 303-309.

WYLIE, A. P. I949. Fohn Innes Hort. Inst. Ann. Rept. for 1948. ZIRKL., C. 1935. The Beginnings of Plant Hybridisation. Philadelphia. 